\title{
MASTER
}

\section{HOURLY VARIABILITY OF SAMPLE CHEMISTRY DURING PRECIPITATION EVENTS AND ITS RELATIONSHIP TO METEOROLOGICAL PARAMETERS}

Gilbert S. Raynor and Janet V. Hayes

August 1979

ATMOSPHERIC SCIENCES DIVISION DEPARTMENT OF ENERGY AND ENVIRONMENT

BROOKHAVEN NATIONAL LABORATORY ASSOCIATED UNIVERSITIES, INC.

UNDER CONTRACT NO. DE-AC02-76CHO0O16 WITH THE

UNITED STATES DEPARTMENT OF ENERGY 


\section{DISCLAIMER}

This report was prepared as an account of work sponsored by an agency of the United States Government. Neither the United States Government nor any agency Thereof, nor any of their employees, makes any warranty, express or implied, or assumes any legal liability or responsibility for the accuracy, completeness, or usefulness of any information, apparatus, product, or process disclosed, or represents that its use would not infringe privately owned rights. Reference herein to any specific commercial product, process, or service by trade name, trademark, manufacturer, or otherwise does not necessarily constitute or imply its endorsement, recommendation, or favoring by the United States Government or any agency thereof. The views and opinions of authors expressed herein do not necessarily state or reflect those of the United States Government or any agency thereof. 


\section{DISCLAIMER}

Portions of this document may be illegible in electronic image products. Images are produced from the best available original document. 


\title{
HOURLY VARIABILITY OF SAMPLE CHEMISTRY DURING PRECIPITATION EVENTS AND ITS RELATIONSHIP TO METEOROLOGICAL PARAMETERS
}

\author{
Gilbert S. Raynor and Janet V. Hayes
}

August 1979

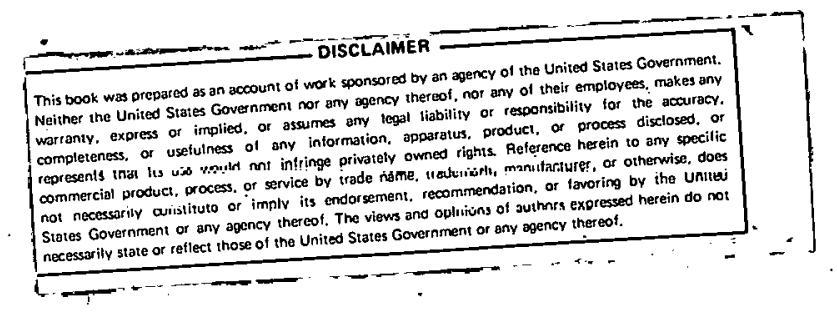

ATMOSPHERIC SCIENCES DIVISION DEPARTMENT OF ENERGY AND ENVIRONMENT

BROOKHAVEN NATIONAL LABORATORY

UPTON, NEW YORK 11973 


\section{DISCLAIMER}

This book was preparied as an account of work sponsored hy an agency of the United States Government. Neither the United States Government nor any agency thereof, nor any of their employees, makes any warranty, express or implied, or assumes any legal liability or responsibility for the accuracy, completeness, or usefulness of any information, apparatus, product. or process disclosed, or represents that its use wnuld not infringe privately owned rights. Reference herein to any specific commercial prod-

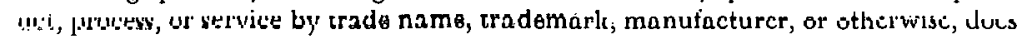
not necessarily constitute or imply its endorsement, recommendation, or favoring by the United States Government or any agency thcrcof. The views and opiniuns of authors expressed herein do not necessarily state or reflect those of the United States Government or any agency thereof.

Printed in the United States of America Available from

National Technical Information Service

U.S. Department of Commerce

5285 Port Royal Road

Springfield, VA 2'2161

Price: Printed Copy ; Microfiche

AO2 


\section{ABSTRACT}

Data from hourly precipitation samples taken at Brookhaven National Laboratory from June 1976 to May 1979 were analyzed to determine the hourly variability within precipitation events with respect to the event means for each of the chemical measurements. These included conductivity and concentrations of hydrogen, nitrogen, sulfate, ammonium, chloride, and sodium ions. The coefficient of variation (S.D. $/ \bar{x}$ ) was found for each variable in each event of three hours or more. Events were then classified by length, season, precipitation rate, and by meteorological parameters and the variability of the coefficient of variation computed for each class. Results are presented in a series of tables. 


\section{INTRODUCTION}

Hourly precipitation samples have been taken at Brookhaven Nationa1 Laboratory (BNL) since June 1976, using an automatic sequential precipitation collector designed and built at the Laboratory.1,2 These samples are analyzed for $\mathrm{pH}$, conductivity, and concentrations of nitrogen, sulfate, ammonium, chloride, and sodium ions.

A primary purpose of the sampling program is to document changes in precipitation chemistry within precipitation events and to relate these changes to causative or associated meteorological factors. Longer range objectives are to determine the mechanism by which pollutants are incorporated into precipitation and to determine the source regions of the pollutants.

Statistical analyses of first-year data and of data from the first two years have been reported. 3,4 A brief description of the program with several case studies of changes within events was given by Raynor. 5 The purpose of this report is to document the variability of hourly measurements of chemical constituents within precipitation events as a function of meteorological parameters without regard to the temporal sequence of changes. A later study will examine temporal changes in relation to changing meteorological conditions.

\section{METHODS}

Methods used for sampling and for chemical analyses were described previously, as was the information recorded with each sample. 3,4 Methods used for statistical analyses of data were also explained in the same reports.

For this study, the hourly chemical measurements within each event of three hours or more were analyzed to find the arithmetic mean, standard deviation, minimum, maximum, and number of samples. The coefficient of variability (S.D. $\sqrt{x}$ ), where $\bar{x}$ is the arithmetic mean and S.D. is the arithmetic standard deviation, was selected as a measure of variability within the event, computed for each chemical measurement, and treated as a new variable.

The events were then classified by season, by meteorological parameters, by duration of the precipitation event, and by average precipitation rate. The class assigned for each event was that which occurred most frequently during the event. The mean and other statistics of the coefficients of variability were then computed for each class. As in previous cepurls, 3,4 a few cases for which chemical measurements were doubtful and all measurements near the limit of detectability of the analytical instruments were excluded frum the andyses.

\section{RESULTS}

Results are presented in tabular form. Table 1 shows the variability of hourly chemical measurements within precipitation events for all cases for the seven chemical measuremente. Tablc 2 shows the same information 
classified by length of event. The data are classified by season in Table 3 and by synoptic type in Table 4. In Table 5, the data are subdivided by precipitation type, and in Table 6 by precipitation rate. They are classified by wind direction in Table 7, by wind speed in Table 8, and by temperature in Table 9. These data are presented for the use of other investigators and as a base for future analytical studies which will be presented elsewhere.

\section{ACKNOWLEDGMENTS}

Numerous individuals made this study possible. John McNeil assisted in design and construction of the sampler. He and Rickey Petty were responsible for its operation and for collection of the samples. Chemical analyses were performed by Mary Kinsley, Cleveland Dodge, Tom McGee, Dan Spandau, and Robert Wilson. Continued support for this project was provided by Paul Michael, Leonard Newman, and Ceorge Hendrey.

\section{REFERENCES}

1. Raynor, G. S. and McNeil, J. P., The Brookhaven Automatic Sequential Precipitation Sampler, BNL 50818, 1978.

2. Raynor, G. S. and McNeil, J.P., An automatic sequential precipitation sampler, Atmos. Environ. 13, 149-55 (1979).

3. Raynor, G. S. and Hayes, J. V., Experimental Data from Analysis of

Sequential Precipitation Samples at Brookhaven National Laboratory, BNL 50826, 1978.

4. Raynor, G. S. and Hayes, d. V., Analytical Summary of Expcrimental Data from Two Years of Hourlÿ Sequential Precipitation Samples at Brookhaven National Laboratory, BNL 51058, 1979.

5. Raynor, G. S., Meteorological and Chemical Relationships from Sequential Precipitation Samples, Proc. 70th Annual Meeting, AIChE, New York, NY, November 13-17, 1977, BNL 22879, 1977. 


\begin{tabular}{|c|c|c|c|c|c|}
\hline \multirow[b]{2}{*}{ Measurement } & \multirow[b]{2}{*}{ Mean } & \multirow[b]{2}{*}{ S.D. } & \multirow[b]{2}{*}{ Min } & \multirow{2}{*}{$\frac{\begin{array}{c}\text { Carly } \\
\text { Cases }\end{array}}{\text { Max }}$} & \multirow[b]{2}{*}{ No. } \\
\hline & & & & & \\
\hline Conductivity $(\mu \mathrm{mhos} / \mathrm{cm})$ & 0.53 & 0.27 & 0.02 & 1.67 & 149 \\
\hline $\mathrm{H}^{+}(\mu \mathrm{eq} / \ell)$. & 0.63 & 0.31 & 0.08 & 1.46 & 170 \\
\hline$N(\mu$ eq $/ \ell)$ & 0.62 & 0.32 & 0.04 & 1.81 & 172 \\
\hline $\mathrm{SO}_{4}^{2-}(\mu \mathrm{eq} / \ell)$ & 0.47 & 0.22 & 0.02 & 1.37 & 155 \\
\hline $\mathrm{NH}_{4}+(\mu \mathrm{eq} / \ell)$ & 0.67 & 0.30 & 0.14 & 1.75 & 169 \\
\hline $\mathrm{Cl}^{-}(\mu \mathrm{eq} / \ell)$ & 0.61 & 0.31 & 0.07 & 1.74 & 125 \\
\hline $\mathrm{Na}^{+}$( eq $\left./ \ell\right)$ & 0.79 & 0.40 & 0.10 & 2.44 & 144 \\
\hline
\end{tabular}




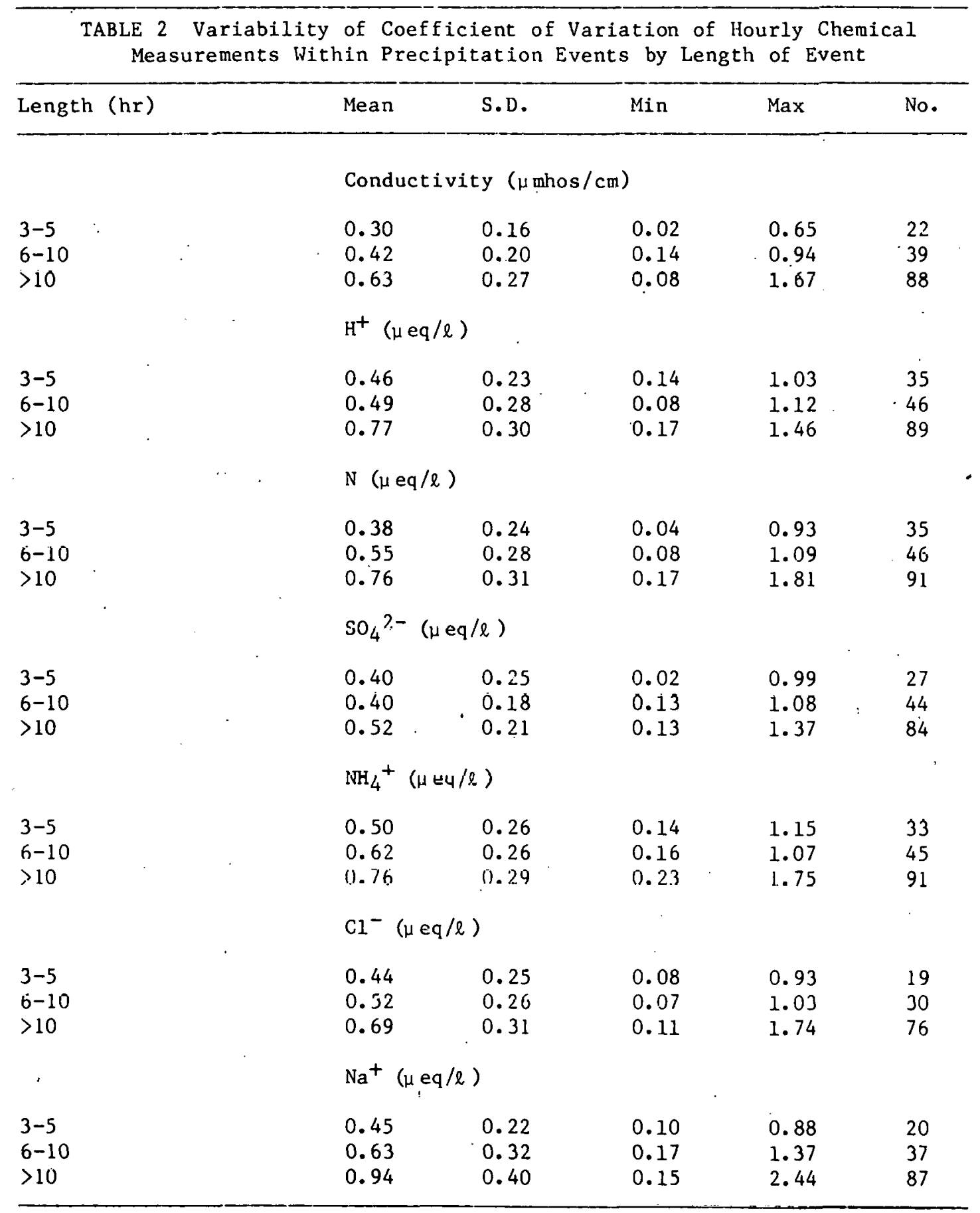




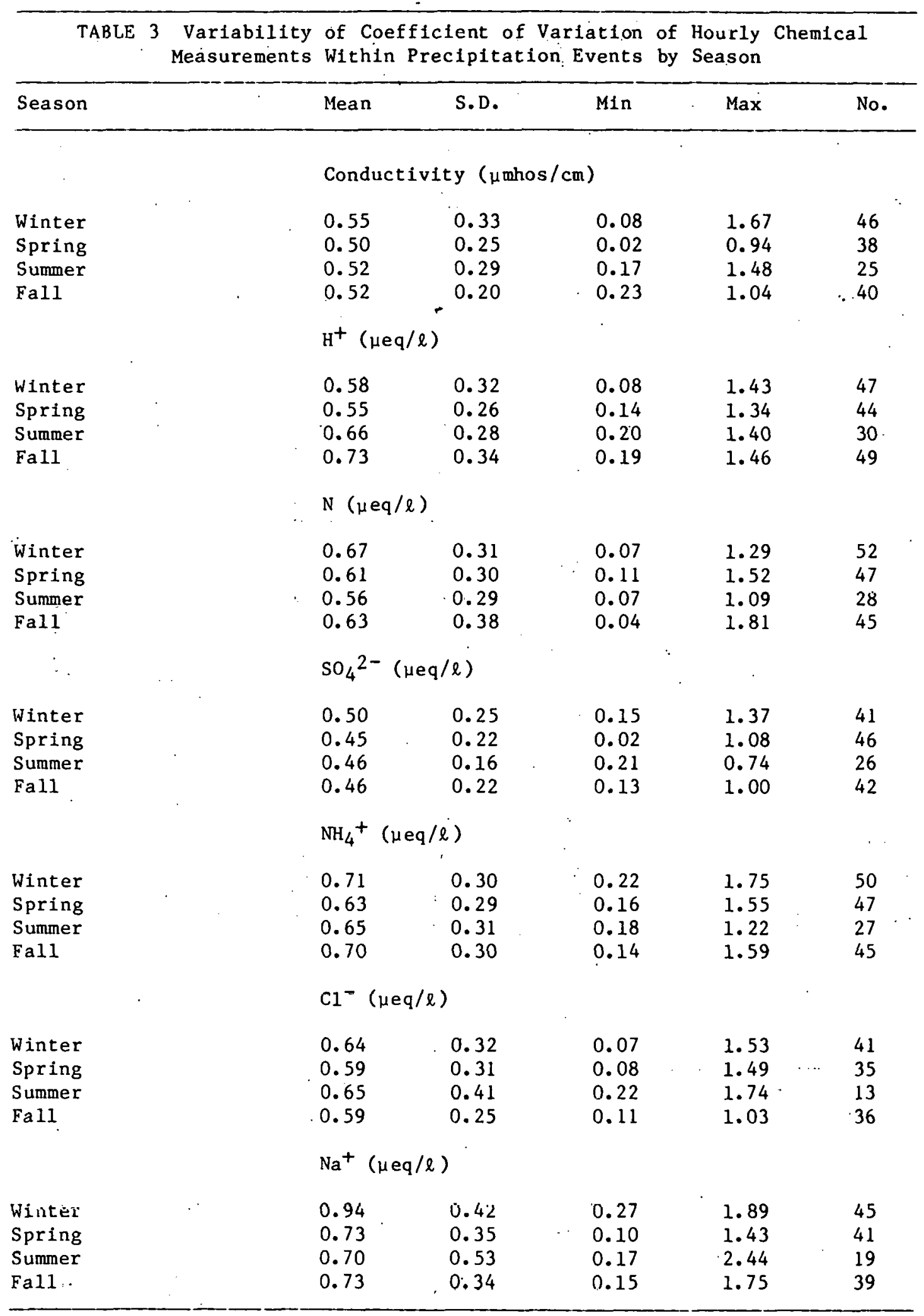




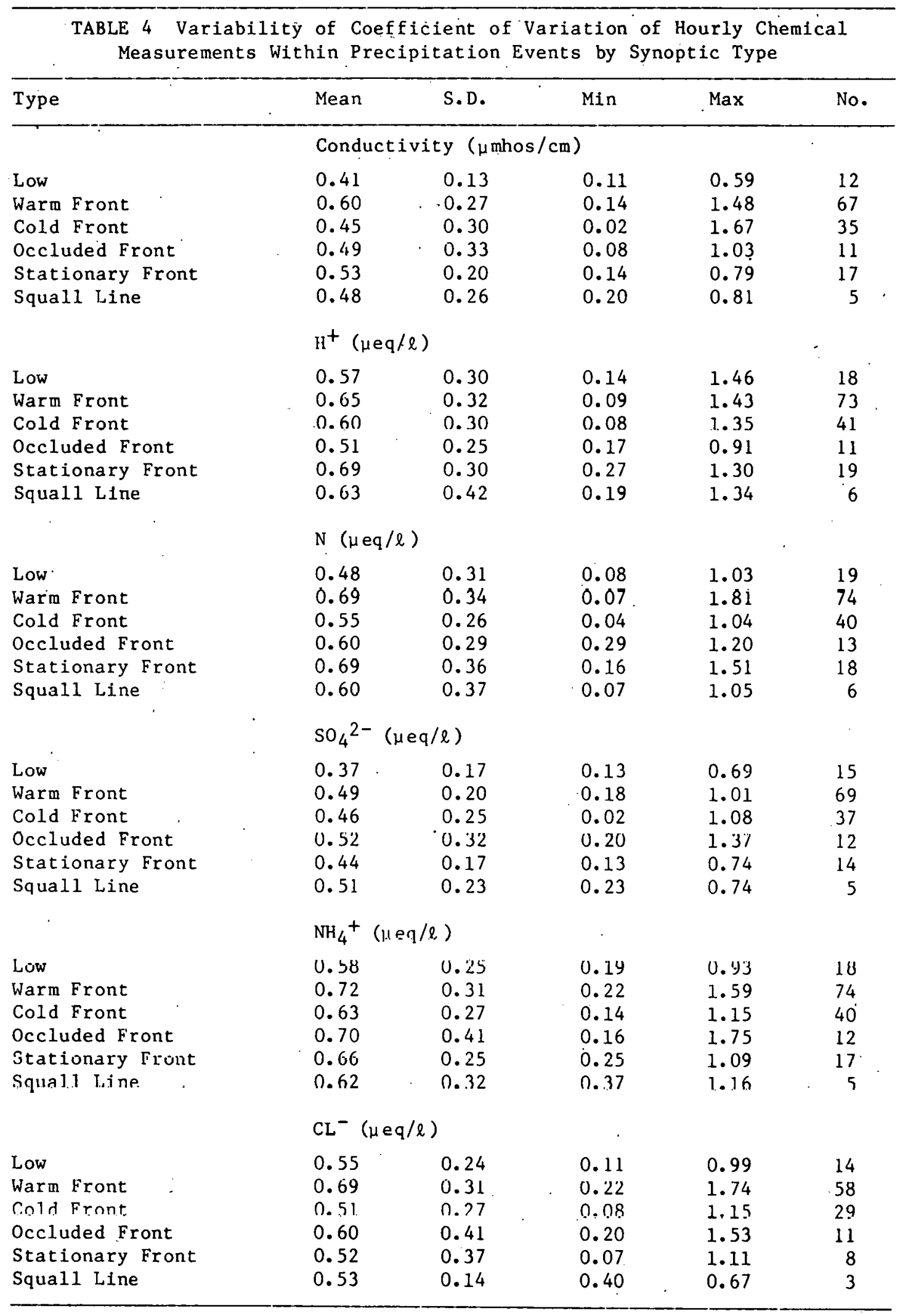


TABLE 4 - Synoptic Type (continued)

\begin{tabular}{llllll}
\hline Type & Mean & S.D. & Min & Max & No. \\
\hline & $\mathrm{Na}^{+}(\mu$ eq/l) & & & \\
& 0.68 & 0.30 & 0.13 & 1.30 & 15 \\
Low & 0.89 & 0.43 & 0.17 & 2.44 & 67 \\
Warm Front & 0.66 & 0.33 & 0.10 & 1.38 & 34 \\
Cold Front & 0.69 & 0.44 & 0.26 & 1.77 & 12 \\
Occluded Front & 0.81 & 0.55 & 0.15 & 1.75 & 10 \\
Stationary Front & 0.81 & 0.22 & 0.51 & 0.97 & 4 \\
Squall Line & & & & & \\
\hline
\end{tabular}


TABLE 5 Variability of Coefficient of Variation of Hourly Chemical Measurements Within Precipitation Events by Precipitation Type

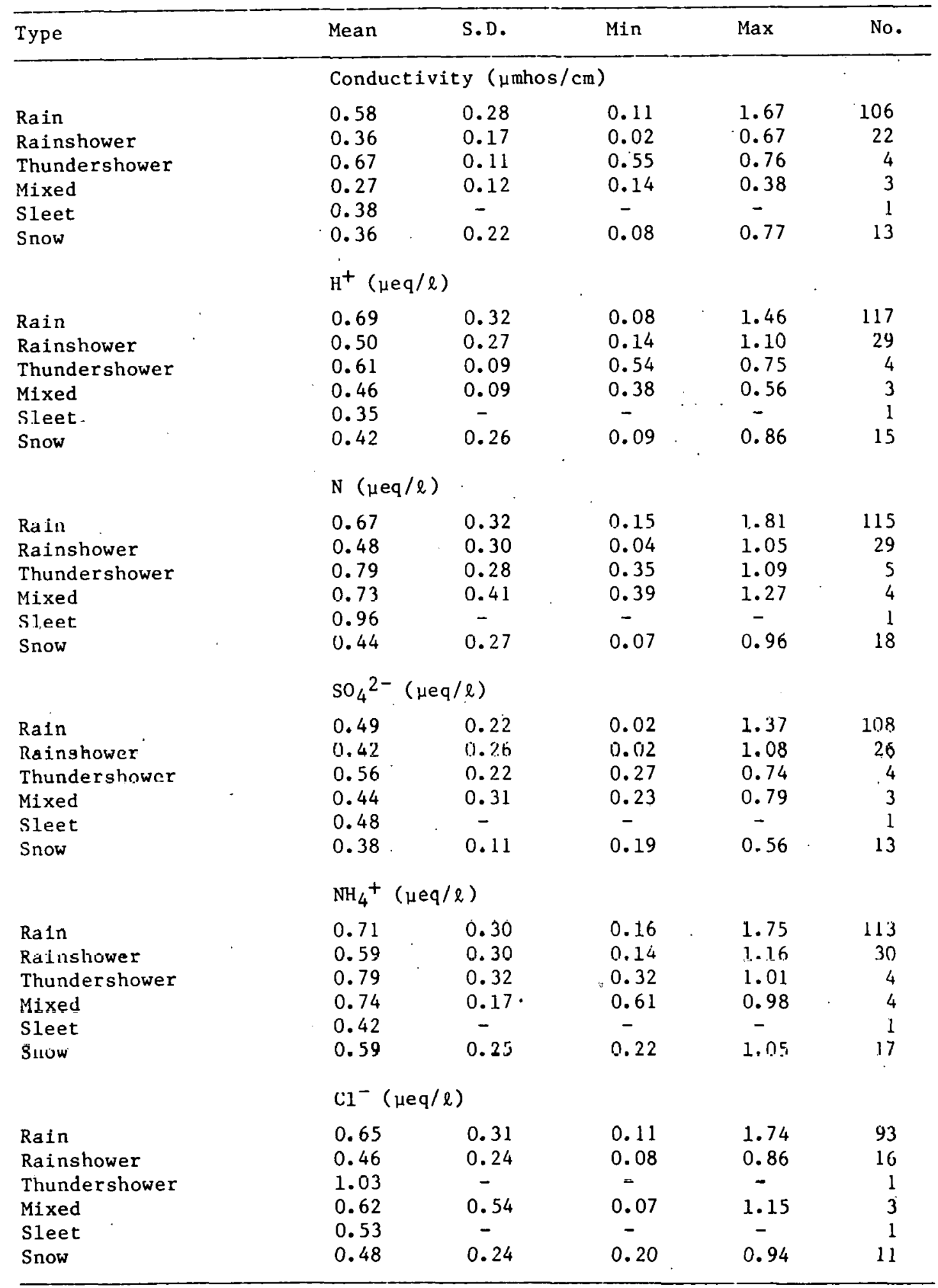


TABLE 5 - Precipitation Type (continued)

\begin{tabular}{llcccr}
\hline Type & Mean & S.D. & Min & Max & No. \\
\hline & $\mathrm{Na}^{+}(\mu \mathrm{eq} / \ell)$ & & & \\
Rain & 0.85 & 0.41 & 0.15 & 2.44 & 106 \\
Rainshower & 0.57 & 0.27 & 0.10 & 0.97 & 19 \\
Thundershower & 0.61 & 0.66 & 0.23 & 1.37 & 3 \\
Mixed & 0.97 & 0.13 & 0.88 & 1.06 & 2 \\
Sleet & 0.76 & - & - & - & 1 \\
Snow & 0.68 & 0.38 & 0.27 & 1.68 & 13 \\
\hline
\end{tabular}


TABLE 6 Variability of Coefficient of Variation of Hourly Chemical Measurements Within Precipitation Events by Average Precipitation Rate

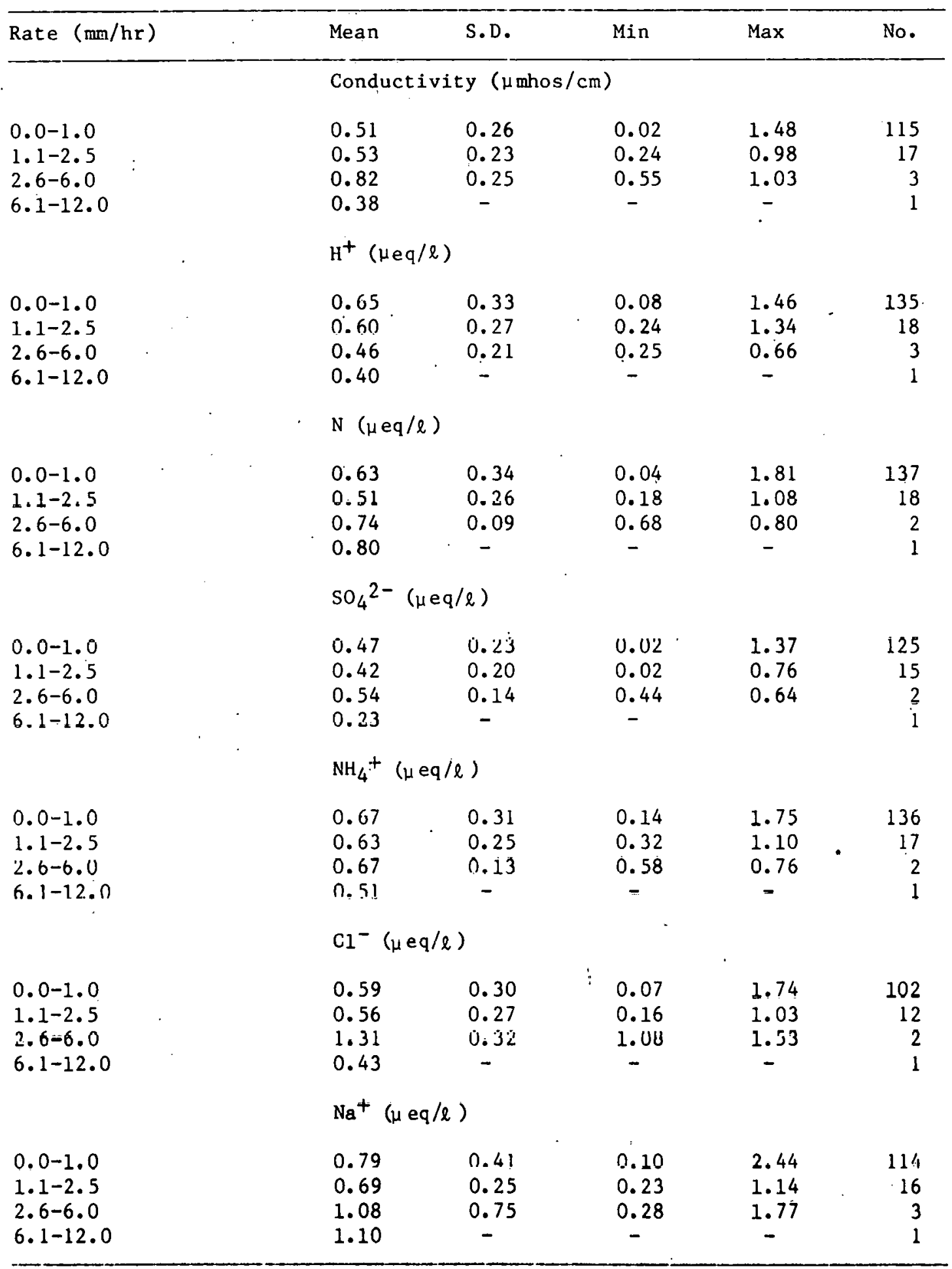


TABLE 7 Variability of Coefficient of Variation of Hourly Chemical Measurements Within Precipitation Events by Wind Direction

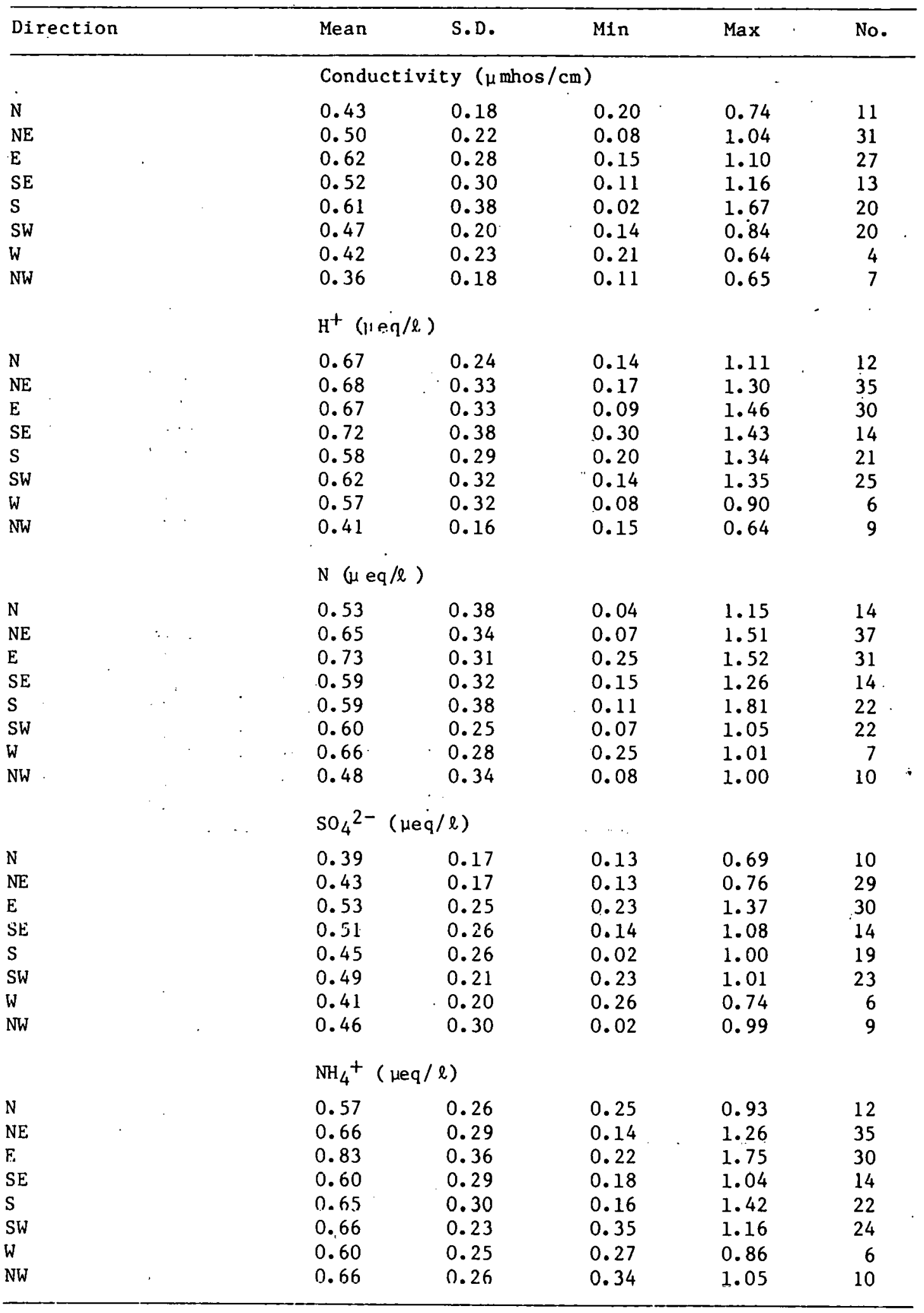


TABLE 7 - Wind Direction (continued)

\begin{tabular}{|c|c|c|c|c|c|c|}
\hline Direction & & Mean & S.D. & Min & $\operatorname{Max}$ & No. \\
\hline & & \multicolumn{5}{|c|}{$\mathrm{Cl}^{-}(\mu \mathrm{eq} / \ell)$} \\
\hline $\mathrm{N}$ & & 0.46 & 0.26 & 0.22 & 0.82 & 6 \\
\hline $\mathrm{NE}$ & & 0.58 & 0.28 & 0.07 & 1.15 & 28 \\
\hline E & & 0.69 & 0.26 & 0.31 & 1.53 & 26 \\
\hline$S E$ & & 0.63 & 0.32 & 0.11 & 1.13 & 11 \\
\hline $\mathrm{S}$ & & 0.64 & 0.34 & 0.08 & 1.15 & 19 \\
\hline SW & & 0.51 & 0.24 & 0.11 & 1.03 & 19 \\
\hline W & & 0.49 & 0.11 & 0.41 & 0.56 & 2 \\
\hline \multirow[t]{2}{*}{ NW } & & 0.51 & 0.32 & 0.16 & 0.81 & 4 \\
\hline & & \multicolumn{3}{|c|}{$\mathrm{Na}^{+}(\mu \mathrm{eq} / \ell)$} & & \\
\hline $\mathrm{N}$ & & 0.73 & 0.44 & 0.15 & 1.44 & 8 \\
\hline $\mathrm{NE}$ & & 0.75 & .0 .35 & 0.26 & 1.75 & $3 i$ \\
\hline$E$ & & 0.88 & 0.38 & 0.18 & 1.77 & 28 \\
\hline SE & & 0.69 & 0.39 & 0.13 & 1.30 & 13 \\
\hline $\mathrm{s}$ & '. & 0.84 & 0.45 & 0.10 & 1.50 & 21 \\
\hline SW & & 0.77 & 0.34 & 0.27 & 1.37 & 18 \\
\hline W & & 0.74 & 0.21 & 0.57 & 0.97 & 3 \\
\hline NW & & 0.61 & 0.37 & 0.27 & 1.33 & 7 \\
\hline
\end{tabular}


TABLE 8 Variability of Coefficient of Variation of Hourly Chemical Measurements Within Precipitation Events by. Wind Speed

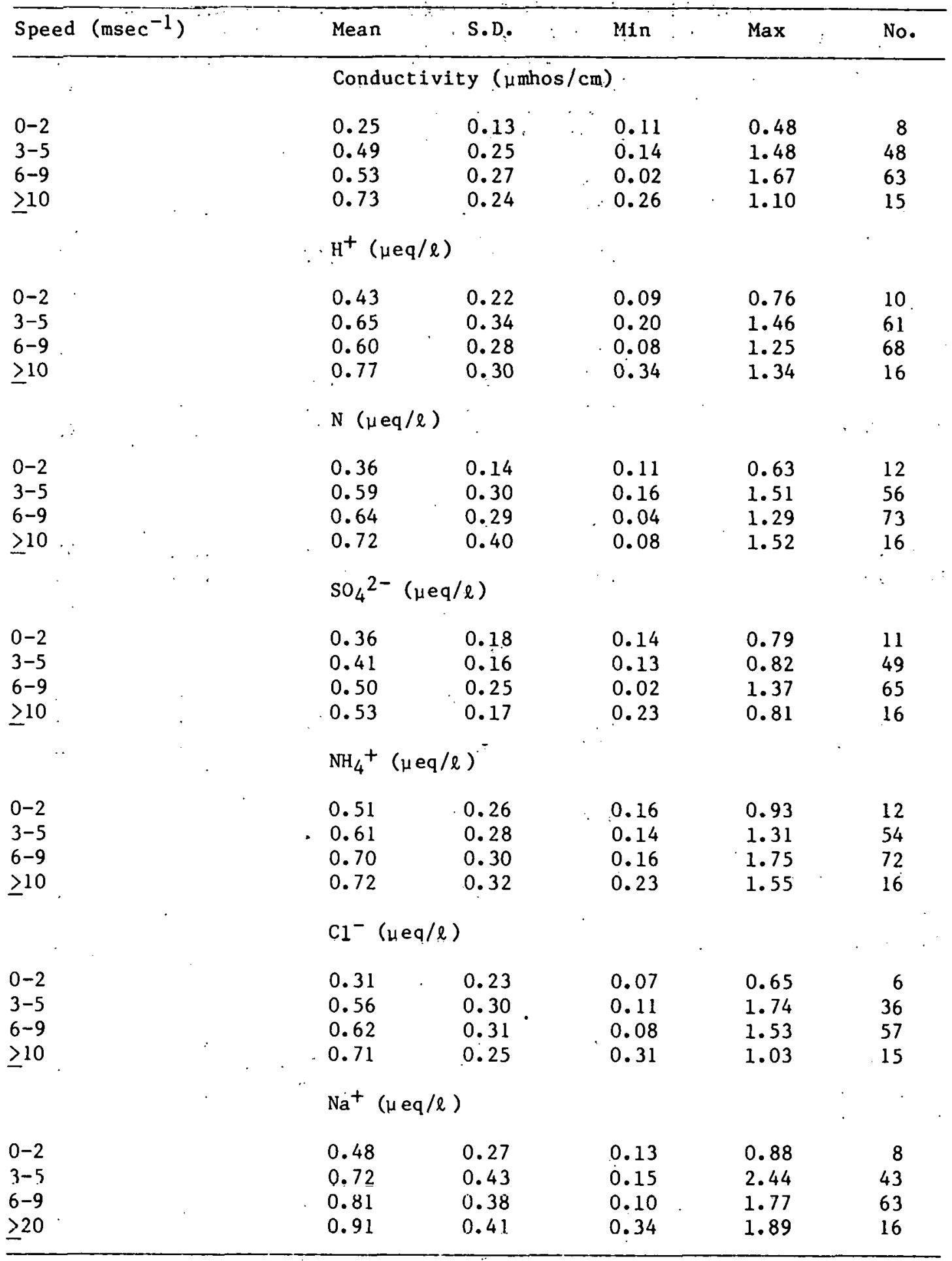


TABLE 9 Variability of Coefficient of Variation of Hourly Chemical Measurements Within Precipitation Events by Air Temperature

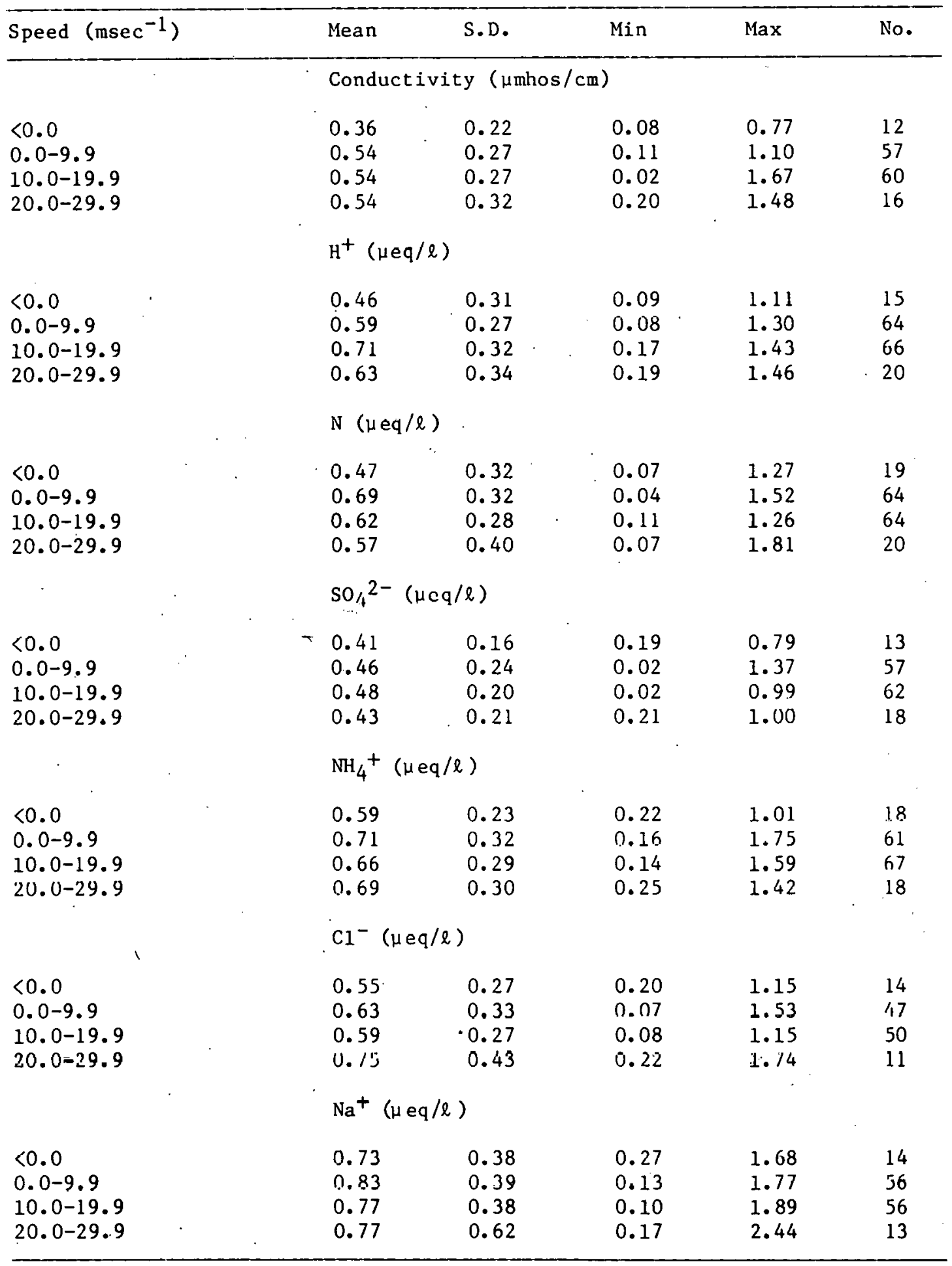

